\title{
SPORT DIPLOMACY AND STATE SOVEREIGNTY: CASE STUDY ON INDONESIA'S EFFORT TO GUARD THE SOVEREIGNTY OF PAPUA
}

\author{
Erni Eriza Siburian, Arie Afriansyah \\ Faculty of Law, Universitas Indonesia \\ E-mail: arieafriansyah@gmail.com
}

\begin{abstract}
Various efforts are made by Indonesia to maintain sovereignty over Papua. One of the efforts taken by the Government of Indonesia is to conduct sports diplomacy through sports cooperation with Melanesian Searhead Group (MSG) member countries. MSG is one of the most intense international organizations to raise the issue of independent Papua. Through descriptive research with normative juridical approach, the authors examine the rules / legal principles relating to how the role of sports diplomacy as a public diplomacy strategy in maintaining the sovereignty of the state: a case study of Indonesia's efforts in maintaining sovereignty in Papua. Based on this, the researchers concluded that sports diplomacy is an important and effective diplomacy tool in maintaining the sovereignty of the state and can create good image of a country where sports can be used as a tool to show togetherness and bring people closer from different background without being associated with differences in race, skin color, religion, or characteristics.
\end{abstract}

Keywords: Sovereignty, State sovereignty, Sports cooperation, Diplomacy, Sport diplomacy.

\section{A. INTRODUCTION}

State is the oldest subject of international law because it emerged as the first subject of international law which later followed by the emergence of other international legal subjects. According to international law only the state has sovereignty, that is, a supreme authority that is not under the control of another country (Adolf, 2015:2). Characteristically, the element of sovereignty is very important in a country. This is because the weakness of the state is measured not on its military or governmental system, but rather on the ability to safeguard the territory which is another form of sovereignty (Junaidi, 2016: 117).

The absence of sovereignty can certainly be considered to be systemic for a country. Various countries in the world could be destroyed due to efforts to safeguard weak sovereignty such as Unisoviet, some Middle Eastern countries and other countries including Indonesia that failed to maintain sovereignty over East Timor.

In terms of maintaining sovereignty, it is inseparable from issues that can threaten the sovereignty itself, one of which is the emergence of a separatist 
movement. Several separatist movements have emerged in Indonesia such as GAM (Gerakan Aceh Merdeka), OPM (Organisasi Papua Merdeka), RMS (Republic Maluku Selatan) and in some areas leading to separatist actions such as in West Java and Central Kalimantan.

Many factors explain the emergence of separatism, including history, economic imbalances, political injustices, and feelings marginalized by the political and economic system. This problem is becoming increasingly complex because globalization and openness make those involved have more freedom to move beyond the national borders. OPM arose when one of the areas in Indonesia that is Papua is debated about its status within Negara Kesatuan Republik Indonesia (NKRI).

Conflict in Papua stems from Indonesia's claim to Papua as part of the territory of NKRI where Papua belongs to the Indies territory which is inherited to Indonesia. Further problems arose which ultimately contributed to the emergence of separatist movements. The research results of the Indonesian Institute of Sciences (LIPI) reveal the four root problems of the emergence of problems in Papua, namely (Elisabeth, 2011):

1. Marginalization that happened to the people of Papua.

2. The occurrence of developmental failure that can be seen from the inequality of development results.

3. The issue of Papuan political status.

4. Violations of human rights.

Meanwhile, the efforts of the separatist movement in Papua, that is OPM for Papuan independence continue to be done. Overseas, the OPM figures continue to lobby for the leadership of the South Pacific countries to be accepted into the Melanesian Spearhead Group (MSG) as well as to gain support for Papuan independence.

In order to stem the support of MSG against OPM on the issue of independent Papua, Indonesia adopted appropriate strategies to safeguard sovereignty over Papua. In addition to accelerating development in Papua, the Government of Indonesia has also begun to adopt more elegant and respectable approaches such as approaches through diplomacy. The diplomacy approach is done to maintain good relations between Indonesia and the Pacific countries, especially MSG member countries. Pacific Island Region, especially MSG member countries have an important role for Indonesia's sovereignty, especially regarding the problems of Papua. Sense of solidarity as fellow Melanesians make movements that want Papua to get a warm reception in Melanesian countries who are incorporated into MSG.

One of the tools of diplomacy that Indonesia uses to improve and strengthen relationships with MSG is sport or better known as sport diplomacy. According to Stuart Murray sees the use of sport as a means of diplomacy in a positive form. Murray believes that with universal values, exercise can serve as a 
tool for showing togetherness and bringing people together from different backgrounds and can spread positive values such as discipline, tolerance, and mutual respect (Murray, 2012: 2). While sport does not necessarily improve conflicts between two or more countries, it can be used as a medium to open the path of peaceful dialogue rather than military use.

History records several instances where sport is used as a means of diplomacy in achieving the national interest of a country. In 1971 came the "ping pong diplomacy" that successfully melt the relationship between the United States (US) and China that had heated up because of the cold war. The ping-pong diplomacy first took place in 1971 when the US table tennis team paid a visit to China for a match with Chinese ping-pong players. This historic visit was first proposed by the United States Nonprofit National Committee. The match then led to a visit by then US President Richard Nixon to China in 1972. This visit continued on the establishment of diplomatic ties between the two countries beginning in 1979, which also ended the isolation of China from the outside world.

Former South African President Nelson Mandela has also used sports as a means of diplomacy. After being elected President of South Africa in 1994, Mandela has a tough task of uniting black people with whites after the Apartheid era. Mandela then used the 1995 Rugby World Cup in South Africa to conduct national reconciliation. The result is very positive, many black communities provide support for the South African rugby squad (Springboks), which are mostly controlled by white players (Wibowo, 2014).

In addition, cricket is also used to melt the tension between India and Pakistan relations. The cricket match between the two countries marked the meltdown of tension between the two countries (Pasricha, 2012). Although there has been no agreement between the two countries on the Kashmir crisis, the meltdown of the two countries is the first step to resolve the issue through channels favorable to both countries.

From some of these events, can be seen how successful the use of sports as a means of diplomacy to achieve the interests of a country. This can also be done by Indonesia by using sports as a diplomacy tool to strengthen relationships with MSG. In an interview with Diplomat Madya at the Directorate of East Asia and Pacific Ministry of Foreign Affairs, Mrs. Dyah Galuh said that to silence the issue of free Papua in the MSG forum is not enough by strengthening bilateral relations with MSG member countries. Governments need to build and strengthen relationships with MSG institutionally through regional cooperation. The upgrading of Indonesia's membership in MSG as an observer to an associate member at the 20th MSG Summit at Honiara, Solomon Island on June 5, 2015, is a good opportunity for Indonesia to get closer and strengthen its relationship with MSG. 


\section{B. PROBLEM STATEMENTS}

Thus, to examine further on how the role of sport diplomacy as a strategy of public diplomacy in maintaining the sovereignty of the state (case study of Indonesia's efforts to guard sovereignty in Papua) will then be discussed about sovereignty disorder in Papua, state sovereignty and diplomacy, and will be analyzed on sovereignty Indonesia over Papua and the role of sport diplomacy in safeguarding Indonesia's sovereignty over Papua.

\section{DISCUSSION AND RESEARCH RESULT}

\section{C.1. Disturbance of sovereignty in Papua}

\section{Conflict in Papua}

The conflict in Papua stems from Indonesia's claim to Papua as part of the territory of NKRI where Papua belongs to the Indies territory which is inherited to Indonesia. When Indonesia proclaimed its independence on August 17, 1945, the Government of Indonesia continued to divide the administrative territory as was applicable during the Dutch colonial period. At that time, Papua was still a part of the Maluku Provision.

Faced with the steps taken by the Government of Indonesia, the Dutch conducted a number of maneuvers. In order to realize its interests in Papua, the Netherlands at the Round Table Conference (KMB) in The Hague on 23 August to 2 November 1949 showed its intense efforts to delay the settlement of the status of the Papua region. In fact, however, the discussion on the Papua issue as mandated by the KMB agreement was never implemented. Furthermore, in 1954 Indonesia's permanent representation at the UN included the West Irian issue on the UN agenda. The move was followed by the cancellation of the KMB agreement by the Indonesian side on May 3, 1956.

Then President Soekarno at that time called for a military operation known as Operation Trikora (Tri Komando Rakyat). This operation ended on August 15, 1962 when Indonesia and the Netherlands signed the New York Agreement. One of the contents of the New York Agreement was that the Dutch handed West Irian to the UN, the Unites Nations Temporary Executive Authority (UNTEA), which was held on May 1, 1963. The 1962 New York Agreement was later confirmed by Resolution No.1752 of 196

New York Agreement 1962 approved the implementation of the assessment of the opinion (the act of free choice) for the people of Papua. This provision became the basis of the Papuan people to carry out Penentuan Pendapat Rakyat (PEPERA) which was held on July 14 to August 2, 1969. The result of this opinion stated that the majority of Papuans decided to join Indonesia and then take note in the General Assembly of the UN General Assembly XXIV through Resolution No.2504 dated 19 November 1969. Since then West Irian (Papua) was declared officially back to the Republic of Indonesia (Gere, 2015: 108). 
Since the establishment of Papua as an integral part of NKRI, there are still many who claim it as political engineering by Indonesia to defend Papua. Movement of separatism in Papua and then many emerging. Starting from the raising of the Morning Star flag in some areas to the shooting of civilians by armed civilian groups.

\section{The form of disturbance of sovereignty in Papua.}

Various problems emerged that could threaten Indonesia's sovereignty in Papua. The forms of disturbance of sovereignty in Papua can be seen as follows :

\section{a. Declaring the 'Country' of Papua}

The result of the Deen Hag agreement (KMB 1949) was less favorable to the Dutch, the anti-Indonesian seeds began to be implanted among the Papuans. The Dutch expelled the nationalism of the "Papuan People" and confirmed the promise of the Papuan people to self-determination which politically tends to be interpreted as "independence". Various attempts were made by the Dutch to lay the groundwork for the establishment of the 'State of Papua' including sending Nicolaas Jouwe and Marcus Kaisiepo to Fiji to attend the South Pacific Commission conference in April 1950.

\section{b. Demanding Referendum}

This movement is driven by 2 (two) elements, namely Komite Nasional Papua Barat (KNPB) and Aliansi Mahasiswa Papua (AMP). These two groups of young Papuans have in recent years intensely criticized the socio-political situation in the land of Papua. Their basic struggle is to demand a referendum again to determine the political status of Papua. The KNPB group is based in Papua, whereas AMP generally consists of Papuan student activists studying outside Papua, especially in Java, Bali and Sulawesi.

\section{c. Armed Movement}

The shootings in Papua, whether carried out by armed OPM groups or by security forces, have occurred several times. The armed movement in Papua is not merely an ideological background to independent Papua, but also rigged with the conditions of injustice commonly felt by Papuans. The conditions have been emerging since the New Order era, such as the absence of meritocracy principles within the Papua Provincial Government, where the strategic position within the regional government structure tends to be dominated by certain ethnic Papuans. This narrow nationalism then widened to the ethnic non-Papuan migrants who gradually began to dominate the economic sector. The reform measures undertaken by the Government seem slow, even the result is so insignificant that it fails to prevent the widening social gap between Papuans and Papuans.

\section{d. Lobby Movement}

There are several groups of OPM who have been guerrillas abroad. They are scattered in several countries. These groups include West Papua National Coalition for 
Liberation (WPNCL) chaired by Andy Ayamiseba, headquartered in Port Villa, Vanuatu, Free West Papua Campaign (FWPC) led by Benny Wenda in England and West Papua National Authority (WPNA) led by Jacob Rumbiak in Australia. These groups continue to lobby politics both for other countries and international organizations to gain support for their efforts to independence of Papua.

\section{The root of the problem in Papua}

Aside local movements, foreign interference also contributes to the complexity of solving problems in Papua. Some events indicate that an indication of foreign intervention in the Papuan problem really occurred. The actors are very diverse, ranging from specific community communities, NGOs, researchers, journalists, to political leaders. Even active state officials are involved, such as Prime Minister Vanuatu. Vanuatu is one of the countries in the South Pacific region which is considered very consistent in supporting the separation of Papua from NKRI. Prime Minister Vanuatu has noted several times raised the issue of Papua in the UN forum:

1) At the UN Annual Session of the 68th Session of September 28, 2013, Vanuatu's Prime Minister Moana Carcasses Katokai Kalosil asked the United Nations to appoint a special representative to investigate alleged human rights abuses in Papua province, and their political status. He stated that the Papuans hope to the UN as the highest hope (United Nations, 2013).

2) On March 4, 2014, Moana Carcasses Katokai Kalosil, PM Vanuatu at the time delivered his speech before the 25th UN Human Rights Assembly. In the presence of these UN leaders, he expressed concern about the situation experienced by the Melanesian people in Papua. Moana also questioned commitments in UN Human Rights sessions which year by year seemed blind and deaf to the problems of indigenous Papuans. At the end of his speech, Moana affirmed his government's commitment to continue fighting for the basic rights of the Papuan people on their own land (Tabloid Jubi: 2014).

3) At the 69th General Assembly of the UN General Assembly on September 29, 2014, Vanuatu's Prime Minister Joe Natuman resumed his statement on Papua. Natuman among others said:

" I cannot close this section of my speech without paying tribute to late Dr. John Ondowame, a Freedom fighter from West Papua who passed away last month while in exile in my country. He was laid to rest in my country as a hero who had fought for the rights to selfdetermination for the people of West Papua. $\mathrm{He}$ and other martyrs had adream that one day the United Nations and all nations advocating and promoting the democratic principles will hear their cries and deliver the promise of a self-determined future. At his funeral service, I stated that his struggle for freedom and justice will continue to be our struggle until colonialism is eradicated (United Nations: 2013)."

4) At the 71st UN General Assembly at UN headquarters, New York, September 2026, 2016. There are six countries that raise the issue of human rights violations in 
Papua at the 71st UN General Assembly. The six countries are Solomon Islands, Vanuatu, Nauru, Marshall Islands, Tuvalu and Tonga. The six Pacific countries raised the issue of Papua in their speech regarding the insistence on the need for a UN factfinding mission to Papua to investigate the alleged human rights abuses there, as well as demands for self-determination for the Papuan people. Vanuatu Prime Minister, Charlot Salwai Tabimasmas, asserted, the UN should take concrete steps related to concern over human rights abuses in Papua. Frequently, the issue of Papua is also raised in the MSG forum. At the 20th MSG Summit in Honiara, Solomon Island on June 5, 2015 The United Liberation Movement for West Papua (ULMWP), an umbrella body of resistance organizations both inside and outside Papua was accepted as an observer in MSG. Support to ULMWP's agenda to become a member of MSG has become a new theme of the political movement of political activists of Papua's independence in the country.

MSG is an intergovernmental organization with this Melanesian race has become a new hope for the Papuan independence group. By utilizing melanesian brotherhood campaigned by member countries of MSG, this group continues to work with South Pacific member countries of MSG to join the struggle for the history of integration of Papua into NKRI. They hope that there will be a third party who can mediate a dialogue with the Indonesian Government to dialogue on the political status. Indonesia as an associate member of MSG strives to strengthen ties with the countries of the South Pacific region as well as to stem the growing support for the ULMWP mission.

The development of an independent Papuan issue in the MSG forum is a serious issue, since institutionally, MSG is protected by the UN under the "Agenda of the Principles of Cooperation Among the Independent States of Melanesia". The agreement signed in Port Vila on 14 March 1988 includes MSG as the official UN body under the Pacific Islands Forum (PIF) (Kumbakarna: 2015). Indonesia's vigilance is increasingly demanded after the 46th PIF Summit in Port Moresby, Papua New Guinea on September 7-11, 2015 addresses the issue of human rights abuses in Papua.

\section{Indonesia's Authority in Papua}

Incidents within a country, including separatist insurgencies, are internal affairs of the country. The law applicable to the handling of insurrection events is the domestic jurisdiction of the country concerned. Other countries are obliged to respect it (Parthiana, 1990: 85). The same principle applies in the case of Papua. State authority is the right of Indonesia to complete it must be respected by other countries. The authority of Indonesia in Papua is (Gere, 2015: 276):

\section{a. Law enforcement}

In its authority to maintain the integrity of the territory of sovereignty, the state through law enforcement agencies is authorized to punish any citizen who proves to 
be detrimental to the interests of state law. The state needs that authority or power because without power, the administration of the state, whether executive, legislative, and judicial can not work. Such power is included in the internal aspect of sovereignty, in which the state has the ultimate power to administer its territory (interne souverniteit). It is with that power that the state can impose the will on its country (Gere, 2015: 278).

Nevertheless, the power of the state (internal sovereignty of the state) is also limited by the basic law or constitution and various laws and regulations which are sourced from it so as not to oppress its own people. This is also in line with the principle of a legal state that must be sustained by a democratic system.

\section{b. Using Weapons}

Until now, the status of security in the territory of Papua is the Civilian Order (Tertib Sipil). The same status is also applied in rural areas of Papua whose security conditions are considered vulnerable. With that status, there is no restriction on civil rights. The involvement of the Indonesian National Army (TNI) in security restoration operations, remains in the frame of civil order status rather than in martial law (BBC, 2013).

The presence of the TNI in the territory of Papua, as well as in other areas of Indonesia, is a state defense tool with the task of implementing state defense policies to uphold state sovereignty, maintain territorial integrity and protect the nation's safety, conduct military operations for war and military operations other than war, and actively participate in regional and international peace-keeping duties. The affirmation of the principle is regulated in the main task of the TNI, namely in Article 7 paragraph (2) of Law Number 34 of 2004 on the Indonesian National Army (TNI).

On the basis of these provisions, the presence of TNI in the territory of Papua is part of carrying out basic tasks of the TNI as stipulated in Article 7 paragraph (2) of Law Number 34 of 2004. As for the actions of rebel groups, the TNI has sufficient authority to handle them. The presence of the state security apparatus in a region is a manifestation of the presence of the state within its sovereign territory. The State as the owner of the last authority within its territorial boundaries has the authority to take necessary measures to ensure the security, social order, and welfare of the people. However, the use of weapons is only done to impose legal obedience (Gere, 2015: 287).

\section{c. Giving Special Autonomy (Otsus)}

In the context of Papua, special autonomy (otsus) can mean a balance built with the legal construction between the sovereignty of the state and the expression of the identity of the ethnic group. This can be found in the history of Otsus for Papua Province. Enactment of Law Number 21 of 2001 accompanied by a number of expectations (Gere, 2015: 239): 
(i) armed separatist groups guerrillas in the forests are expected to disband by themselves as they all return to the NKRI's administration and build their villages;

(ii) no more Papuans are campaigning for independent Papuans overseas because the indigenous Papuans are protected, empowered, and guaranteed for their present and future survival within NKRI;

(iii) no more Papuans are displaced in Papua New Guinae because they have all returned to the land of Papua;

(iv) no more resistance groups such as KNPB appear, because all Papuans welcome Otsus Papua with joy.

The above expectations have not yet been fully realized. The presence of KNPB is one of the indicators that the Special Autonomy Law has not been implemented consistently, effectively and thoroughly. Regardless of the KNPB's 'referendum oriented' mission, its rejection of the Special Autonomy policy in the Papuan land could be a valuable input to immediately fix Otsus for the advancement and welfare of the Papuans. As long as Otsus has not been able to address the problems and basic needs of indigenous Papuans, so long as new groups will emerge.

The concrete nature of the Government in developing Papua is seen from the development program implemented by the Working Cabinet led by President Joko Widodo today, as well as by the previous government. The development program is implemented to realize a positive change for progress in the land of Papua.

One of the programs that is currently the priority of Jokowi's government is the construction of Trans-Jaya road along $4,325 \mathrm{~km}$. The program, which was due to be completed in 2018, is believed to provide significant stability for Papua's change. The trans-Papua road will connect several roads namely the highway connecting Sorong, Manokwari, Wondama Nabire, Enarotali, Sugapa, Bioga, Ilaga, Sinak, Mulia, Ilu, Karubaga, Elelim and Jayapura road segments. While the lower lane is Wamena road, Habema, Mapenduma, Paro, Kenyam, Dekai, Oksibil, Iwur, Tanah Merah, Waropko, and Merauke (Ratumakin: 2015).

\section{d. Rejecting Foreign Intervention}

State-owned sovereignty basically contains the basic responsibility for protecting individuals, property and to carry out government functions in its territory. The existence of the state's sovereignty is a fundamental principle in international law. This principle gave birth to another principle called nonintervention principle, a principle which obliges every sovereign state to not take action to interfere in the domestic affairs of other countries in inter-state relations.

Foreign intervention on the internal problems of a country clearly disrupts the country's sovereignty. In principle, the state has full rights in maintaining its territorial integrity from all threats from within and from outside. Other countries that have been aggressively intervening in nationalizing the Papuan issue, regardless of any motive, are clearly at odds with the principle of state sovereignty. In addition, the intervention of a state on the internal problems of other countries is 
also contradictory to the principle of non-intervention contained several documents or instruments of international law, namely:

a. UN Charter Article 2 paragraph (4) and paragraph (7).

b. UN General Assembly Declaration 2131 (XX) December 21, 1965 on Declaration on the inadmissibility of Intervention in the Domestic Affairs of States and the Protection of Their Independence and Sovereignty.

c. United Nations General Assembly Declaration 1970 on Principles of International Law no. 2625 (XXV) concerning Friendly Relations and Cooperation between States in accordance with the Charter of the United Nations.

\section{C.2. State Sovereignty and Diplomacy}

\section{State Sovereignty}

According to Jean Bodien, sovereignty is a state attribute, and a special feature of the state. Sovereignty is the supreme, single, genuine, and eternal power of the state. Sole means there is only one supreme power, so that power can not be divided. Original means that power is not born of any other power. Whereas eternal means the power of the state goes on and on without intermittent (Junaidi, 2016: $115)$.

The sovereignty of a country is often associated with the issue of the extent to which the state has the authority to enforce its policies or state activities. The challenge to a country is absolute and can happen anytime. Therefore, efforts to emphasize a sovereign value within the state are mandatory.

Characteristic of sovereignty is actually more important than region. This is because the weakness of the state is measured not on the strength of the military or the system of government, but rather on the ability to maintain the region which is another form of its efforts to maintain sovereignty. Weaknesses in the absence of sovereignty can certainly be considered to be systemic for a country. Various countries in the world can be destroyed due to its efforts to maintain weak sovereignty. As in Unisoviet, some countries in the Middle East, and other countries including Indonesia can not defend Timor Leste.

\section{Territorial sovereignty}

The territorial sovereignty is the state's sovereignty in exercising exclusive jurisdiction in its territory. It is within this territory that the state has the authority to carry out its national law (Adolf, 2015: 105).

The question of how a country gets its territory in international law is a difficult issue because of the lack of discussion on this issue. The much-discussed is how a country gains its independence and how a unified society meets the elements or criteria of international law in order to become a country or subject of international law and recognized by other countries. 
The next problem is what principle is used to determine a region belongs to a country. In international law, which is still a reference is the principle introduced by Hans Kelsen, namely (Adolf, 2015: 11-115):

\section{a. Principle of Effectiveness}

According to this principle, state ownership of a territory is determined by the effective enactment of national legal regulations in a region. An indicator to find out if an effective rule is to adhere to and enforce national legal regulations in a region. It appears here that Hans Kelsen consistently uses the legal approach as a measure of the effectiveness of the ownership of a territory.

In court decisions, the application of the principle of effectiveness appears in the consideration of the International Court of Justice in the disputes of Pulau Sipadan and Ligitan between Indonesia and Malaysia. The issue of Sipadan Island and Ligitan Island emerged for the first time in September 1969 in the negotiation of the continental shelf boundary in Kuala Lumpur between Indonesia and Malaysia. On that negotiations, Malaysia declared its ownership of both islands located on the coast of Northeast Borneo and on the North West of Sulawesi island. On the contrary Indonesia also demands that the two islands be under its sovereignty (Sugihato, 2015).

On December 17, 2002 the International Court of Justice in its court ruled that the two islands belong to Malaysia on the grounds that the two islands have long been administrated by the United Kingdom and subsequently by Malaysia or otherwise known as the principle of effectiveness. The International Court of Justice states that Malaysia's effective proof of the two islands and over a period of time, among others, that Malaysia since 1917 has undertaken the legislative functions of both islands for example by the issuance of Turtle Protection Regulations, and issuing licenses to catch turtle eggs. Malaysia has also built lighthouses on Sipadan Island and Ligitan Island in 1962 and 1963 which have continued to be maintained since Malaysia's independence. This Malaysian sovereignty activity according to the observation of the Court has never been protested by Indonesia.

All these historical facts are quite convincing that Malaysia has demonstrated its sovereign activity over the two islands and is sufficient to prove the effectiveness of a country's sovereignty requirements over the two islands. In this case, whatever Indonesia has done since 1969 as well as occupying both islands, it will not be able to erase the effectiveness of Britain or Malaysia.

\section{b. Uti Possidetis Principle}

According to this principle, in principle the boundaries of the territory of a new state will follow the boundaries of the territory of the occupying country. Expressed in principle because in reality the boundaries of a country's territory (the old or the new) can change. 
In its later development the International Court of Justice adopted this principle in resolving the state border disputes. In relation to the issue of Papua, the Ambassador of the Republic of Indonesia for the Work of Belgium, Luxembourg and the European Union, Yuri $\mathrm{O}$ Thamrin claimed to have held 'ammunition' in the form of the principle of international law namely the principle of uti possidetis when faced with the issue of Papua.

Yuri explained that Uti Possidetis Juris principle is used to determine the boundaries of a previously colonized state. Namely, its borders follow boundaries when the country is still colonized. That is, for the context of Indonesia, the boundaries of its territory follow the borders of the territory when it was still a Dutch East Indies. With this kind of logic, formerly under Dutch colonial rule (and the territory of the Dutch East Indies), it is fitting for Papua to become part of Indonesia when the declaration of independence is made (Ali, 2014).

The main objective of this principle is to prevent the independence and stability of the newly born nations becoming disturbed or threatened by the existence of a lawsuit against its territorial borders. Since quite a number of border disputes are resolved by applying this principle, Martin Dixon argues that the principle of uti possidetis has now become a principle of costumary law of general application (Adolf, 2015: 114).

\section{c. Prohibition of Resort to Force}

This principle prohibits a country from acquiring a territory using the force of a weapon. This principle includes the UN Charter, the 1955 Asian African Conference Result, the various instruments issued by ASEAN, and others.

\section{d. The Principle of Peaceful Dispute Resolution}

Under this principle, all disputes arising out of territory, in this case claims to ownership status over territory, shall be resolved peacefully. These peaceful means are outlined in international law as contained in Article 33 paragraph (1) of the UN Charter, which states:

" The parties to any dispute, shall, first of all, seek a solution by negotiation, inquiry, mediation, conciliation, arbitration, judicial settlement, resort to regional agencies or arrangements, or other peaceful means of their own choice."

\section{e. Self Determination Principle}

This principle affirms the respect of the will of the people in determining the territorial ownership status. This principle contrasts with principle 3 above, namely the prohibition of the use of violence in obtaining territory, but must respect how the will of the people themselves determines its will over the territory it inhabits. 
In relation to the Papua issue, the Ambassador of the Republic of Indonesia for the Work of Belgium, Luxembourg and the European Union, Yuri $O$ Thamrin stated that the exercise of the right to self-determination can only be done once and for all. This refers to the custom of international law. Seluri Yuri believes that based on these principles, foreign rongrongan over the issue of Papua can be overcome. Moreover, in international forums, Indonesia has many friends. This is different from the Vanuatu delegation who often raise the issue of Papua in international forums. Nevertheless, the Government of Indonesia should continue to maintain the situation and security in Papua in order to avoid human rights violations.

\section{Diplomacy}

Diplomacy is one of the important instruments in the implementation of a country's foreign policy. It is a key tool in the achievement of national interests relating to other countries or international organizations. Through diplomacy a country can build an image of itself in the framework of the development of bargaining power or state branding (Shoelhi, 2011: 73). In achieving the national interest, each country has its own approach. There is an approach through hard power as well as a soft power approach that promotes a cultural approach.

One form of the use of instruments with a soft power approach is through public diplomacy. Public diplomacy is a state instrument, so it is the state that has access to manage public diplomacy for short-term interests and long-term interests (Rachmawatie, 2016: 46). But in its development, public diplomacy is not only to put the state as the main actor. In this case the non-state actors have their own way in interpreting the relationship between countries.

\section{Sport as a Diplomacy Instrument}

Stuart Murray also stated that sports diplomacy or sport diplomacy is under the broad umbrella of public diplomacy where diplomatic activity and representation of the state play a role by sportsmen. According to Stuart Murray sees the use of sport as a means of diplomacy in a positive form. Murray believes that with universal values, exercise can serve as a tool for showing togetherness and bringing people together from different backgrounds and can spread positive values such as discipline, tolerance, and mutual respect (Murray, 2012: 2). While sport does not necessarily improve conflicts between two or more countries, it can be used as a medium to open the path of peaceful dialogue rather than military use.

Sport diplomacy can be used to describe the participation of sports such as athletes and trainers in diplomacy programs. Here are some of the events where sport is used as a diplomacy tool: 


\section{a. American and Chinese Ping-Pong Diplomacy}

History also noted the emergence of "Ping Pong Diplomacy" in 1971 that successfully melt the relationship between the United States (US) with China that had heated up because of the cold war. The ping-pong diplomacy first took place in 1971 when the US table tennis team paid a visit to China for a match with Chinese ping-pong players. This historic visit was first proposed by the United States Nonprofit National Committee. The match then led to a visit by then US President Richard Nixon to China in 1972. This visit continued on the establishment of diplomatic ties between the two countries beginning in 1979, which also ended the isolation of China from the outside world.

\section{b. Basketball Diplomacy of the United States and China}

The basketball diplomacy used in the US and Chinese relations is an alternative for both countries to improve the cold-tying relations of Tiananmen events in 1989. The entry of the NBA market, the professional basketball league of the United States into China in 1990 became the entry point the practice of sports diplomacy (basketball diplomacy) in the interaction between the United States and China. Basketball Diplomacy became one of the continuing efforts to use sports diplomacy in the United States-China relationship after in 1971 had used Pingpong Diplomacy as one of the efforts of normalization of relations between the two countries at that time.

Basketball diplomacy efforts by two countries include exchange of basketball athletes between the two countries, holding inter-state friendlies, active in charities involving basketball athletes of two countries, forming a special committee engaged in sports as a facilitator between communities with countries, such as BECA (the Burreau of Educational and Cultural Affairs) with a sports united mission. In addition, the practice of basketball diplomacy is also done by people-to-people as practiced by Yao Ming, an NBA professional basketball player, by introducing US culture to China and vice versa.

The positive response of the US and Chinese governments related to the use of Basketball Diplomacy in a two-state relationship is indicated by an official statement by the two-state officials. On January 14, 2014, US President Barack Obama inaugurated the exchange program as part of United States sports diplomacy along with the NBA in the Global All-Star Basketball Sports Visitor Program, or along with the NBA champion's 2013 visit to the White House in Washington.

During the visit of Chinese Vice Premier Liu Yandong to NBA Houston Rockets basketball team headquarters, where Tsinghua high school students underwent a NBA basketball training program, Liu Yandong revealed that, "Ping Pong Diplomacy opened the gate for establishing China-U.S. diplomatic relations in early years, and today, we need more sports diplomacy such as basketball diplomacy to continually enhance the mutual understanding and friendship between the peoples of China and the United States" (Pambudi, 2016: 112). The statement affirms that the Chinese government is supporting the implementation of basketball diplomacy. 


\section{c. Diplomatic Cricket of Pakistan and India}

India and Pakistan are two countries that always fight and never agree on the territory of their country especially the contested territory of Khasmir. But as the times and borders grew, the border dispute case grew even more so after the signing of an agreement on the incorporation of Kashmir with India occurred October 26, 1947 (Judge, 2015).

Diplomatic efforts between the Pakistani and Indian governments are also held by holding several Cricket games to ease tensions and try to normalize relationships to build stable communications. Cricket sport is well-liked in both countries, and the two countries have faced each other in international matches.

Not only once did Cricket's sport be used to defuse tension and also one of the diplomacy instruments between Pakistan and India, but in 2011 the sport of Cricket was reused after Pakistani Prime Minister Gilani accepted an invitation from the Indian government to attend a cricket semifinal sport match between Pakistan and India held in Mohali, India. The invitation was made to thaw out a tense relationship when a terrorist attack in Mumbai in 2008 was conducted by a group of armed Pakistani men. The cricket match between the two countries marked the meltdown of tension between the two countries (Pasricha, 2012). Although there has been no agreement between the two countries on the Kashmir crisis, the meltdown of the two countries is the first step to resolve the issue through channels favorable to both countries. From the event of cricket diplomacy between Pakistan and India it can be seen that sports diplomacy can create an alternative diplomacy that allows countries to move beyond their foreign policy. Cricket is used by both countries to reduce tensions and explore the possibilities to normalize relations between the two countries, and to open borders to resume direct talks on security.

There are several reasons that show that sports can be one of the best instruments of diplomacy, including the influence of the greater the sport. Exercise can enhance dialogue or communication between individuals and means of integration within a multicultural community. Exercise can build inter-ethnic experiences and develop trust in others. Cooperation and fierce competition against each other in sports teaches to respect each other without being associated with race, color, religion, or characteristics that are different from one another.

The world community prefers more refined approaches through soft power, such as sports. In modern times, sports, culture and diplomacy can be a separate force as a foreign policy tool of a country.

\section{C.3. Analysis of Indonesian Sovereignty over Papua and Role of Sport Diplomacy in Maintaining Indonesian Sovereignty over Papua}

\section{Indonesia's sovereignty over Papua}


With regard to Indonesia's sovereignty in Papua, there is no question or doubt. Under international law, Indonesia has sovereignty and sovereignty in Papua based on:

\section{a. Plebiscites (General Election)}

Plebiscite is the transfer of a territory through the choice of its inhabitants, after the holding of elections, referendums or other means elected by the population. Peblisite or referendum or act of free choice for the people of Papua as the implementation of the provisions of Article XVIII New York Agreement 1962.

Based on the 1962 New York Agreement, Papua conducted Penentuan Pendapat Rakyat (PEPERA) of 1969 from July 14 to August 2, 1969. The results of this opinion suggest that Papua is part of Indonesia and the majority of Papuans decide to join Indonesia. PEPERA's results were then recorded (take note) in the General Assembly of the XXIV UN Assembly through Resolution No. 2504 dated November 19, 1969. Thus, Papua is an integral part of the territory of the sovereignty of the Republic of Indonesia and proves that since that time Indonesia has sovereignty over the region.

\section{b. Principle of Effectiveness}

According to this principle, State ownership of a territory is determined by the effective enactment of national legal regulations in a region (Adolf, 2015: 111). An indicator to find out if an effective rule is to adhere to and enforce national legal regulations in a region. With regard to the problems of Papua, Indonesia's sovereignty based on this principle can be seen from:

\section{(1) Provision of Special Autonomy}

The national legal regulation that is applied specifically for the Papua region is Law Number 21 of 2001 on Special Autonomy for Papua Province.

The autonomy granted to Papua is special and different from the autonomy imposed in other areas. The specificity can be clearly seen from the point of autonomy at the provincial level, in contrast to Law Number 32 of 2004 which places the emphasis of autonomy on districts. This is in fact an acknowledgment that Papuans are a social entity, while districts or cities should only be seen as administrative or territorial divisions.

Special Autonomy of Papua is a product of the Central Government to reduce conflict in Papua. The expectations with the enforcement of Law Number 21 of 2001 on Special Autonomy for Papua Province is (Gere, 2015: 239):

(i) armed separatist groups guerrillas in the forests are expected to disband by themselves as they all return to the NKRI's administration and build their villages;

(ii) no more Papuans are campaigning for independent Papuans overseas because the indigenous Papuans are protected, empowered, and guaranteed for their present and future survival within the Unitary State of the Republic of Indonesia;

(iii) no more Papuans are displaced in Papua New Guinae because they have all returned to the land of Papua; 
(iv) no more resistance groups such as the West Papua National Committee (KNPB) arose, as all Papuans welcomed Otsus Papua with joy.

\section{(2) Using weapons}

The presence of the TNI in the territory of Papua, as well as in other areas of Indonesia, is a state defense tool with the task of implementing state defense policies to uphold state sovereignty, maintain territorial integrity and protect the nation's safety, conduct military operations for war and military operations other than war, and actively participate in regional and international peace-keeping duties.

The affirmation of the principle is stipulated in Article 7 paragraph (2) of Law Number 34 of 2004 on the Indonesian National Army. On the basis of these provisions, it is explained that the presence of the TNI in the territory of Papua is part of the main duty of the TNI as stipulated in Article 7 paragraph (2) of Law Number 34 of 2004. Thus, against the actions of separatist groups, the TNI has sufficient authority to deal with them. The presence of the state security apparatus in a region is a manifestation of the presence of the state within its sovereign territory. The State as the owner of the last authority within its territorial boundaries has the authority to take necessary measures to ensure the security, social order, and welfare of the people. However, the use of weapons is only done to impose legal obedience (Gere, 2015: 287).

\section{(3) Enforcing the law in Papua}

In its authority to maintain the integrity of the territory of sovereignty, the state through law enforcement agencies is authorized to punish any citizen who proves to be detrimental to the interests of state law. This is based on the theory of state sovereignty (theorie van de staatssouvereiniteit). Based on this theory, law is adhered to because it is the country that wants it. Law is the will of the state and the state has infinite power (macht / power) (Samidjo, 1986: 140).

Based on this theory, the person (citizen) can be punished because the state is sovereign so that only the state itself is entitled to punish someone who breaks the order in society. The state is regarded as something that creates the rule of law.

Separatist movement, a common phenomenon in some countries that intend to separate from the state, which from the beginning was fought and obeyed together. One example of state action in law enforcement in Papua was that in July 2016, Timika Police Department arrested 69 (sixty nine) activists of the Komite Nasional Papua Barat (KNPB) for allegedly committing criminal acts of treason. The demonstration by the group was conducted in order to mobilize votes for the United Liberation Movement for West Papua (ULMWP) to join the Melanesian Spearhead Group (MSG). 
Police officers of the Republic of Indonesia as law enforcement officers in the framework of the task of public service, uphold the law, and protect the public from the actions of persons who violate the law, including here from the disturbance of separatist and rebel groups, are legitimate as long as he has carried out his obligations accordingly with the terms and conditions of their profession. This is in accordance with the mandate of the 1945 Constitution Article 30 paragraph (4) stating that:

"The State Police of the Republic of Indonesia as a state instrument that maintains the security and public order has the duty to protect, protect, serve the community, and enforce the law."

\section{Foreign Intervention}

Another thing that causes how eksisnya disturbance of state sovereignty in Papua that is the external factor that is foreign intervention. Foreign interference or foreign intervention on the problems of Papua is real. Foreign countries which have been actively intervening in nationalizing the Papua issue, irrespective of any motive, are clearly contrary to the principle of state sovereignty, namely the principle of non-intervention as contained in several international legal instruments:

\section{a. UN Charter}

The principle of non-intervention

is implied in the provisions of Article 2 paragraph (4) which states that:

"All Members shall refrain in their international relations from the threat or use of force against the territorial integrity or political independence of any state, or in any other manner inconsistent with the Purposes of the United Nation.

Furthermore, the provisions of Article 2 paragraph (7) which states that:

"Nothing contained in the present Charter shall authorize the United Nations to intervene in matters which are essentially within the domestic jurisdiction of any state or shall require the Members to submit such matters to settlement under the present Charter; but this principle shall not prejudice the application of enforcement measures under Chapter VII."

This provision requires that the United Nations be banned from interfering in the domestic affairs of a country except in order to preserve peace under Chapter VII of the UN Charter.

\section{b. UN General Assembly Declaration no. 2131 (XX) on December 21, 1965}

The United Nations General Assembly in 1965 issued an important declaration prohibiting the intervention of a state against another country entitled 'Declaration on the inadmissibility of Intervention in the Domestic Affairs of States and the Protection of Their Independence and Sovereignty'. Paragraph 1 of the Declaration stipulates the prohibition intervention either directly or indirectly or 
for any reason whatsoever, neither the intervention of domestic affairs nor the foreign affairs of a country.

\section{c. UN General Assembly Declaration 1970}

The provisions on the prohibition of intervention may also be found in the Declaration on Principles of International Law Number 2625 (XXV) concerning Friendly Relations and Co-operation between States in accordance with the Charter of the United Nations, which states that states are obliged not to intervene in the domestic affairs of other countries.

Non-intervention principle violation does not have to be in the form of physical attack. The intensity of Papuan issues discussed in countries such as Vanuatu, PNG, Britain and Australia is also a violation of the principle of nonintervention. Due to the fact that the discussion on Papua issues, especially the discussion on the political status of the Papua region has been responded by the support groups of the Papuan independence movement in Papua, both by political groups and armed groups as a form of support for them to realize an independent Papua. As a result, they are intensifying their actions, such as demonstrations calling for a referendum, as well as attacks on TNI posts and shooting of security forces as they have been (Gere, 2015: 224).

Regarding the intervention of MSG in the issue of independent Papua, in an interview with Mrs. Dyah Galuh, Diplomat Madya at the Directorate of East Asia and Pacific Ministry of Foreign Affairs said that the issue of Papua's independence received warmly in the MSG forum is only because of historical problems only. MSG member countries are less aware of the real conditions in Papua. The issue of human rights abuses in Papua is the main reason MSG intervenes on the issue of independent Papua. In addition, he also stated that it is also inseparable from the political interests of MSG member countries. The issue of independent Papua is often raised in the election campaign of Prime Minister Vanuatu to gain the trust of Parliament and the people of Vanuatu. Similar thing also done by Solomon.

\section{Indonesia's Efforts to Guard sovereignty over Papua}

\section{a. Development in Papua}

Settlements and development continue to be done in Papua, especially during the reign of President Joko Widodo. In RAPBN 2016, for example, the budget for Papua through the allocation of special autonomy funds is around Rp. 5.4 trillion. West Papua gets around Rp. 2.3 trillion. The amount is still combined with additional infrastructure funds in the context of Papua and West Papua special autonomy of about Rp3.3 trillion. The amount of infrastructure additional funds is divided respectively for Papua around Rp. 2.2 trillion and West Papua around Rp. 1.1 trillion.

Furthermore, in the RAPBN 2016 the Government also allocates Rp. 46.9 trillion allocated $90 \%$ equally to each village and the remaining $10 \%$ by population, 
poverty, area, and village geographic difficulty. Governor Lukas Enembe at the Office of the Governor of Papua explains the allocation of APBN 2017 funds for the region increased by Rp. 56.85 trillion. The amount consists of DIPA ministries / agencies or work units Rp. 13.68 trillion and DIPA transfers to regions and village funds reached Rp. 43.17 trillion. However, the tens of trillions of funds are not entirely managed by the Papua Provincial Government, but part of the ministries / agencies and work units amounts to Rp13.68 trillion. The remaining Rp. 43.17 trillion is also part of the district / city's APBD and village funds so that the amount reached Rp43, 17 trillion (Deri, 2017).

One of the programs that is currently the priority of Joko Widodo government is the construction of Trans Jaya road along 4,325 km. The program, which was due to be completed in 2018, is believed to provide significant stability for Papua's change. The trans-Papua road will connect several roads namely the highway connecting Sorong, Manokwari, Wondama Nabire, Enarotali, Sugapa, Bioga, Ilaga, Sinak, Mulia, Ilu, Karubaga, Elelim and Jayapura road segments. While the lower lane is Wamena road, Habema, Mapenduma, Paro, Kenyam, Dekai, Oksibil, Iwur, Tanah Merah, Waropko, and Merauke (Ratumakin, 2015). The construction of the trans-Papua road has already shown a good progress where the 3,800-kilometer (km) TransJakarta TransJakarta road was successfully opened. This is evident in President Joko Widodo's visit to the trans-Papua road of Wamena to Kenyam in Papua Province on May 10, 2017 (Aron, 2017).

The efforts to complete the Trans-Papua development confirm the strong intention of Jokowi-Jusuf Kalla's government to speed up the road infrastructure. This is a concrete form of the Government's attention to the welfare of the Papuan people in order to meet the expectations of the enactment of Law Number 21 of 2001 on Special Autonomy for Papua Province so that internal sovereignty disturbance from internal can be hold.

\section{Creating Relationships with Melanesian Spearhead Group (MSG)}

Regarding the issue of Papua that is often raised by MSG member countries in MSG forums as well as in other international forums, Indonesia whose membership status has increased to associate members in MSG strives to strengthen relations with the countries of the south pacific region as well as to stem the growing support for mission ULMWP. In this regard, the Government of Indonesia has begun to adopt more elegant and respectful approaches such as political approaches in the domestic context and diplomacy or negotiation approach in the context of influencing the international world with the intention that the international community will continue to recognize that Papua is an integral part of the Unitary State of the Republic of Indonesia.

As an associate member, Indonesia continues to commit to promoting close and concrete cooperation with MSG to explore potential and address common development challenges. The improvement of Indonesia's status in MSG is an effort to strengthen cooperation with countries in the Pacific. In addition to 
strategic geographical location adjacent to the Pacific region, Indonesia is home to 11 (eleven) million Melanesian people residing in 5 (five) Provinces of Papua, West Papua, Maluku, North Maluku and East Nusa Tenggara.

In making relationships with MSG, one of Indonesia's approach is through sport diplomacy. Sport diplomacy is done by establishing sports cooperation with MSG countries. Until now, Indonesia has established sports cooperation with Fiji and Papua New Guinea (PNG). Sports cooperation with the Republic of Fiji was signed on the occasion of President Susilo Bambang Yudhoyono's official visit to Nadi, Fiji in 2014. While sports cooperation with PNG was signed on the occasion of Prime Minister PNG's visit to Indonesia from June 16-18, 2013.

\section{a. Indonesia-PNG Cooperation in Sports Sector}

The bilateral relationship between Indonesia and PNG has almost never experienced open conflict which has serious impact on bilateral relations, although there are groups of Indonesian security troublemakers based in PNG areas that are difficult to reach. The enhancement of Indonesia-PNG bilateral relations throughout 2013 has given strategic weight of bilateral relations and cooperation, particularly in the context of establishing close economic and development cooperation between the two countries (Ministry of Foreign Affairs of the Republic of Indonesia, 2015: 50).

Improving relations between the two countries is marked by the signing of Indonesia-PNG cooperation in sports field signed in 2013 in Jakarta. Cooperation is the basis for both countries to implement various sports programs. This cooperation is also a step of mutual benefit of both countries especially to facilitate the needs of each of the two countries. From the political side, this cooperation is expected to prevent the emergence of conflict in the border areas of both countries and the main can strengthen bilateral relations between the two countries in order to improve the good image of Indonesia in the eyes of the Pacific region countries, especially PNG.

In promoting people-to-people contact, the two countries organize sports activities at the border. Indonesia-PNG cross-border race is an annual agenda of routine activities. By taking a distance is 10 (ten) kilometers with the start route from Wutung (Sandaun Province, PNG) and finish at Skouw (Papua Province, RI). The main purpose of this competition is to strengthen the relationship between citizens in the two countries directly adjacent.

Jahar Gultom, the Indonesian Consul in Vanimo at the time, stated that this cross-border run event resulted in enormous effectiveness in building mutual trust between the people residing in Indonesia and PNG. Trust is a provision in improving bilateral relations between the two countries. In addition, he also said that this event has a good momentum to realize the sports cooperation between the two countries (Indonesia-PNG) recently signed by the Minister of Youth and 
Sports of Indonesia and Minister of Sports of PNG in Jakarta on June 16, 2013 (Gultom, 2014 ).

In addition, the football team of Papua, Indonesia Football Association Jayapura (Persipura Jayapura) recorded several times invited by the Government of PNG to participate in the celebration of the independence day of PNG. In 2012 Persipura Jayapura was invited to enliven the independence day of PNG by facing the Oceania championship team, Hekari United (Antara News, 2012). Persipura Jayapura again invited by the PNG Government to participate in the celebration of PNG independence in 2015 (Antara News, 2015).

\section{b. Indonesia-Fiji Cooperation in the Sports Sector}

Indonesia-Fiji relations have generally been well underway and contributed positively to cooperation within the bilateral, regional and multilateral framework. Since 2011, the bilateral relationship between Indonesia and Fiji has reached a new level with the visit of Prime Minister Frank Bainimarama to Indonesia on April 56, 2011, the opening of the Fiji Embassy in Jakarta, and the signing of the Cooperation Agreement / DCA agreement on May 27, 2011.

Improving relations between the two countries is also evident from the visit of the President of the Republic of Indonesia to Nadi, Fiji, June 17-20, 2014 which is the first visit of the head of Indonesian government to Fiji as well as coinciding with the 40th anniversary of diplomatic relations between the two countries and also become Chief Guest in Pacific Islands Development Forum (PIDF) Second Leaders Meeting. The Minister of Foreign Affairs has also held a bilateral meeting with the Foreign Minister of Fiji, Ratu Inoke Kubuabola during the visit of the Foreign Minister and Representative of MSG to Indonesia on January 15, 2014 (Ministry of Foreign Affairs of the Republic of Indonesia, 2015: 47).

Based on the interview with Mr. Dwijayanto Sarosa Putera, Deputy Assistant of Partnership and Sports Award at the Ministry of Youth and Sport of the Republic of Indonesia stated that the implementation of sports cooperation with Fiji continues to be done in order to improve the relationship between the two countries. He conveyed that the visitation of the officials of the two countries has been implemented several times and as a concrete form of Indonesia's commitment to strengthen relations with Fiji is through the implementation of Joint Technical Working Group I (JTWG I) in Suva, Fiji in May 2015. On the execution occasion JTWG I also, Indonesia has organized badminton coaching clinic and exhibition of pencak silat and also at the same time provide sports equipment aid such as badminton racket, soccer ball, and shuttlecock. The development of sports cooperation between the two countries also increased with the implementation of the Second, JTWG on April 2016 in Jakarta.

He hoped that the sporting cooperation of Fiji has made a positive contribution to the improvement of relations between the two countries, especially in the 
interaction of people to people relations, so in the future it is necessary to start cooperation with other southern pacific countries such as Solomon Islands and Vanuatu since both countries are enough active in discussing the issue of Papua.

He added that the sport is considered effective enough to close the relationship with the south pacific region countries, especially to bring people - to - people contacts, considering that sport is an activity that is in great demand worldwide for children, adults, young people, male and female. In addition, the sport is accessible to every race, religion, ethnicity, and citizenship, thus combining individuals and cultures together in peace.

The closer relations between Indonesia and PNG and Fiji are visible from the two countries 'support for Indonesia in several MSG leaders' meetings throughout 2016. This is related to the membership status of the Papuan independence movement (ULMWP) in MSG which has not yet received full membership. Currently ULMWP is only an observer in the MSG forum, while the membership status of Indonesia in MSG increases from observer to associate member. Indonesia itself has an associate member status because it represents 11 million Indonesians with melanesian race background in five provinces namely Papua, West Papua, East Nusa Tenggara, Maluku and North Maluku (Kaha, 2015).

The involvement of PNG and Fiji in the implementation of cooperation between RI-Fiji and RI-PNG in sports is a form of recognition of the two countries on the integrity and sovereignty of the Unitary State of the Republic of Indonesia. The implementation of sports cooperation between RI-Fiji and RI-PNG can actually give a positive contribution to the improvement of Indonesia's relationship with the two countries. Future sports cooperation within the framework of sports diplomacy with both countries and countries of the Pacific region, especially MSG member countries need to be improved to improve the image of Indonesia in the country region. However, bilateral sports cooperation with MSG countries has not had a significant impact on the strengthening of Indonesia's relationships and MSG.

In connection with this, Dyah Galuh said that the Ministry of Foreign Affairs considers sport diplomacy as an important and effective diplomacy tool if used properly. So in the future the Government strengthens the relationship with MSG through sports cooperation in the framework of regional cooperation. Organizing sports events involving MSG member countries is considered to have a greater impact on strengthening Indonesia's relationship with MSG and also contributing to Indonesia's efforts to become a permanent member of MSG.

Furthermore, the Government needs to make a special study related to sport diplomacy and make blue print related to Indonesia sport diplomacy implementation strategy so that it is not only aimed at political interest but also expected to be useful and have positive impact to national sport. 


\section{E. CLOSING}

1. Indonesia has sovereignty and sovereignty in Papua based on:

a. The result of the implementation of plebiscite 1969 on July 14 to August 2 1969, West Irian (Papua) was declared officially back to the Republic of Indonesia. The PEPERA results are then recorded in the General Assembly of the XXIV General Assembly through Resolution No.2504 dated November 19, 1969.

b. The principle of effectiveness, proving that national legal rules apply effectively in the territory of Papua. This is indicated by:

(1) The enactment of special autonomy in Papua based on Law Number 21 of 2001 on Special Autonomy for Papua Province.

(2) The presence of the Indonesian National Armed Forces in the territory of Papua in implementing the state defense policy to uphold the sovereignty of the state, to maintain territorial integrity, and to protect the safety of the nation, to carry out military operations for war and military operations other than war, and to participate actively in the task of maintaining regional peace and international. This is based on the provisions of Article 7 of Law Number 34 of 2004 regarding the Indonesian National Army.

(3) Law enforcement in Papua. During this time, the state through the State Police of the Republic of Indonesia helped maintain security in Papua by arresting separatist groups who interfere with security in Papua. The State through the law enforcement institution ie the State Police of the Republic of Indonesia is authorized to punish any citizen who is proven to harm the interests of state law. This is as seen in the provisions of the 1945 Constitution Article 30 paragraph (4).

2. Intensity of Papua issue discussed by member countries of Spearhead Group (MSG) in both MSG forums, UN, and other international forums that breached non intervention principle as stating in UN Charter Article 2 paragrap (4) and (7), UN General Assembly Declaration no. 2131 (XX) of 21 December 1965 on the Declaration on the inadmissibility of Intervention in the Domestic Affairs of States and the Protection of Their Independence and Sovereignty, and the provisions of Declaration on Principles of International Law Number 2625 (XXV) concerning Friendly Relations and Co-operation between States in accordance with the Charter of the United Nations.

3. Sport diplomacy is one of the important and effective diplomacy tools in maintaining the sovereignty of the state and can create a good image of a country where sport can be used as a tool to show togetherness and bring people closer to different background without being associated with race, religion, or characteristics that are different from one another.

4. The involvement of PNG and Fiji of various sporting activities such as visits of Government of Indonesia and Fiji officials at Joint Technical Working Group I \& II on Youth and Sports Cooperation in Fiji and Jakarta, coaching clinic 
badminton by Indonesian trainers in Fiji, running cross border 10K IndonesiaPNG routinely held every year, as well as PNG Government invitation to Papuan football team Persipura Jayapura to Papua New Guinea can be claimed as a form of recognition and support of both countries on the integrity and sovereignty of Indonesia.

5. Indonesia's Indonesia's diplomacy with MSG has not been maximized and has not had a major impact such as American and Chinese ping pong diplomacy, Pakistan and India cricket, and South African rugby.

\section{BIBLIOGRAPHY}

\section{Books:}

Adolf, Huala, 2015, Aspek-Aspek Negara Dalam Hukum Internasional (Aspects of State in International Law), CV Keni Media: Bandung,.

Gere, Nico, 2015, Merawat Kedaulatan Indonesia di Papua: Revitalisasi Prinsip Kedaulatan dan Prinsip Non-Intervensi dalam Piagam PBB (Treatment of Indonesian Sovereignty in Papua: Revitalization of Sovereignty and NonIntervetion Principle in UN Charter). Antara Publishing, Dept. Penerbitan dan Percetakan: Jakarta.

Junaidi, Muhammad, 2016, Ilmu Negara: Sebuah Konstruksi Ideal Negara Hukum (State Science: An Ideal Construction of Rechtstaat), CV Setara Press: Malang.

Parthiana, I Wayan, 1990, Pengantar Hukum Internasional (Introduction to International Law), Mandar Madju: Bandung.

Shoelhi, Mohammad, 2011, Diplomasi: Praktik Komunikasi Internasional (Diplomacy: International Communication in Practice), Simbiosa Rekatama Media: Bandung.

Kementerian Luar Negeri Republik Indonesia, 2015, Buku Diplomasi Indonesia (Indonesian Diplomacy Book), Kementerian Luar Negeri, Jakarta.

\section{Journals:}

Lukman Pambudi, Triawan, "Peran Publik dalam Diplomasi: Penggunaan Diplomasi Basket dalam Hubungan Amerika Serikat-Cina", (October 3, 2016).

Murray, Stuart, "Sports-Diplomacy: A Hybrid of the Two Halves" ( August 28, 2012).

\section{International Document:}

Agreement Between the Republic of Indonesia and the Kingdom of the Netherlands Concerning West New Guinea (West Irian) (1962).

Charter of United Nations and Statute of The International Court of Justice (1946).

General Assembly Resolution 2131 (XX) of the Declaration on The Inadmissibility of Intervention in The Domestic Affairs of States and The Protection of Their Independence and Sovereignty (1965). 
General Assembly Resolution No. 2625 (XXV) of the Declaration on Principles of International Law Concerning Friendly Relations and Co-Operation Among States in Accordance with The Charter of The United Nation (1970).

General Assemby Resolution No. 34/169, of the Code of Conduct for the Law Enforcement Officials (1979).

\section{INTERNET}

Anjana Pasricha, "India-Pakistan Memulai Lagi Diplomasi Melalui Kriket", https://www.voaindonesia.com/a/india-pakistan-memulai-lagi-diplomasimelalui-kriket/1573479.html, 28 Februari 2012.

Ali, “Uti Possidetis Juris, Prinsip yang Digunakan Indonesia untuk Menjaga Papua”, http://www.hukumonline.com/berita/baca/lt580d876150d84/uti-possidetisjuris--prinsip-yang-digunakan-indonesia-untuk-menjaga-papua, 24 Oktober 2016.

BBC Indonesia, "Indonesia terapkan Operasi Penegakan Hukum di Papua", http://www.bbc.com/indonesia/berita_indonesia/2013/02/130222_rapatkabi net_papua, 22 Februari 2013.

Burhan Hakim, Ahmad, “Analisa Konflik Perbatasan (Khasmir) India-Pakistan", http://www.kompasiana.com/www.burhanhernandez.com/analisa-konflikperbatasan-khasmir-india-pakistan_5559e958739773840218cea0, 16 Juni 2015.

Deri, Ansel, "Papua dan Jokowi",

http://mediaindonesia.com/news/read/105184/papua-dan-jokowi/2017-0518\#, 18 Mei 2017.

Elisabeth, Adriana, "Inilah Empat Akar Masalah Papua Versi LIPI" http://lipi.go.id/berita/single/Inilah-Empat-Akar-Masalah-Papua-VersiLIPI/5919, 29 Oktober 2011.

Gultom, Jahar, "Lomba Lari $10 \mathrm{~K}$ Lintas Perbatasan RI-Papua Nugini", http://www.radioaustralia.net.au/indonesian/radio/onairhighlights/lombalari-10k-lintas-perbatasan-ripapua-nugini/1255078, 28 Januari 2014.

Harto, Sugihato, "Lepasnya Pulau Ligitan dan Sipadan dari NKRI", http://www.kompasiana.com/sugiharto69/lepasnya-pulau-ligitan-dansipadan-dari-nkri_550ee047a333117732ba7e9d, 25 Juni 2015.

Henricus BS Aron, Hans, “Jokowi Kagum 3.800 Km Trans Papua Berhasil Dibuka”, https://finance.detik.com/berita-ekonomi-bisnis/3498227/jokowi-kagum3800-km-jalan-trans-papua-berhasil-dibuka, 11 Mei 2017.

Kaha, Kornelis, "Ras Melanesia Terbanyak Ada di Indonesia", http://www.antaranews.com/berita/526363/ras-melanesia-terbanyak-ada-diindonesia, 29 Oktober 2015.

Ratumakin, Roy, “Jalan Trans Papua Jadi Prioritas Utama”, http://tabloidjubi.com/16/2015/09/08/jalan-trans-papua-jadi-prioritasutama/, 8 September 2015. 
Tabloid Jubi, "Pidato PM Vanuatu di Hadapan Sidang HAM PBB 25: 10 Persen Populasi Papua Telah Dibunuh oleh Tentara Indonesia", http://tabloidjubi.com/16/2014/03/05/pidato-pm-vanuatu-di-hadapansidang-ham-pbb-25-10-persen-populasi-papua-telah-dibunuh-oleh-tentaraindonesia/, 5 Maret 2014.

United Nations, "Vanuatu urges inclusive development, pledges to continue speaking against

colonialism",http://www.un.org/apps/news/story.asp?NewsID=46117\#.WR hMVWiGPb0, 28 September 2013. 